\title{
Aging of Rum in a Hot Chamber ${ }^{1}$
}

\author{
Calixta S. Torres, Juan L. Aguiar, Heriberto Batiz and Iván \\ Hernánde $z^{2}$
}

ABSTRACT

An 18-week prelimınary experiment demonstrated that during the aging of the rum the production of tannins, acids, esters, acetal, and acetaldehyde was accelerated at $115^{\circ} \mathrm{F}, 70 \%$ relative humidity-controlled chamber, as compared to that in average environmental conditions of $88^{\circ} \mathrm{F}$ and $55 \%$ relative humidity. Tolal volume, water and alcohol losses were higher in the hot chamber. A $110^{\circ}$ barreling proof showed better results than $140^{\circ} \mathrm{P}$ in both chambers. Rum tasters did not report significant differences in preference among either the experimental samples or between them and the commercial rum used as reference sample.

\section{INTRODUCTION}

The rum-maturing process begins as soon as the freshly distilled colorless spirit is placed in wood barrels. The filled barrels are normally deposited in bonded warehouses for a period of time at ambient conditions of temperature and humidity. The aging process is terminated with the withdrawal of the spirits from the barrel. The distillate undergoes definite organoleptic and chemical changes which characterize rum and affect its quality $(2,3,4,6,9)$.

The quality of the rum is deeply dependent upon the maturing process. The raw spirit, manufactured in less than 2 days, has to remain in storage for several months or years before it meets the quality requirements of the market.

Many attempts have been made to accelerate the maturing of distilled spirits. One of the approaches is to raise the temperature to accelerate the rates of reactions, which may result in a rapid aging of the raw spirit.

The whiskey industry has studied the influence of raising the temperature of the aging spirit as a process to accelerate the maturation of whiskey. Crampton and Tolman (5) observed that rye whiskey aged in heated warehouses developed higher content of solids, acids, and esters than bourbon whiskeys aged at normal conditions. Valaer and Frazier (11) found that heating spirits in the presence of wood chips for several hours, increased color and furfural. Esters changed very little. Statistical analyses done by Liebmann and Scnerl (7) on the composition of heated, wood-treated whiskeys prior to storage, showed that color, solids, total acids, and tannins were affected, but the difference disappeared after the third year. The acid content ceased to show significant differences as early as one month after treatment and storage.

\footnotetext{
' Manuscript submitted to editorial Board on June 26, 1974.

${ }^{2}$ Assistant Chemists, Chemist, and Chemical Engineer, respectively, Agricultural Experiment Station, Mayaguez Campus, University of Puerto Rico, Río Piedras, Puerto Rico.
} 
The purpose of our study was to observe the changes experienced by rum while aging for 18 weeks in a hot chamber, and to evaluate the usefulness of increased temperature and relative humidity in accelerating rum maturity. The effect of storage degree proof and original barrel volume were also observed.

\section{MATERIALS AND METHODS}

Two equal-sized chambers were used. The Reference chamber was kept at uncontrolled environmental conditions of temperature and relative humidity. Average conditions at this chamber were $80^{\circ} \mathrm{F}$ and $55 \%$ relative humidity. The chamber had two narrow louvered windows open to the outside. The Hot chamber was kept at $115^{\circ} \mathrm{F} \pm 2^{\circ} \mathrm{F}$ and $70 \pm 5 \%$ relative humidity. The only ventilation was that induced by steam and air recirculating for the control of the humidity.

A typical raw distillate produced at the Rum Pilot Plant was diluted with demineralized water to prepare batches of $110^{\circ} \mathrm{P}$ and $140^{\circ} \mathrm{P}$ spirits for use in the experiments.

Eight white oak-charred barrels, used once previously for the aging of whiskey, were used. Prior to the experiments the barrels were washed with demineralized water, and treated with steam to eliminate leaks. Barrels, 55 gal total capacity, were filled with either 50 or 55 gal of rum, weighed and stored in a standing position, side by side, four in each chamber. The poplar wood stopper of each barrel was perforated and an $1 / 8$ in o.d. $\times 1.5$ inch stainless steel tubing was inserted through it. The tube was filled with Dow Cornings ${ }^{3}$ silicone adhesive, which upon drying formed a septum-like stopper. Samples were drawn out of the barrels through these septa with a $30 \mathrm{ml}$ capacity gas-tight hypodermic syringe. Each barrel was sampled weekly during the first 2 weeks of aging and afterwards every month up to 18 weeks. A one-gallon sample was saved from each barrel at the end of the experiment for taste evaluation.

Samples were analyzed by gas chromatography using a dual column Hewlett Packard, Model 5750 chromatograph, equipped with a hydrogen flame ionization detector. A stainless steel column, $18 \mathrm{ft} \times 1 / 8$ in o.d., packed with 5\% Carbowax $20 \mathrm{M}$ on Chromosorb W, 60/80 mesh, was used to determine acetaldehyde, methyl acetate, ethyl acetate, acetal, propyl alcohol, isobutyl alcohol and isoamyl alcohol. Tannins (spectrophotometric), ethyl alcohol (refraction) and total acidity (titration to $\mathrm{pH}$ 8.1) were done following the methods described in the Manual of Analytical Methods of the Rum Pilot Plant (8).

For the organoleptic evaluations, one portion of each of the eight

${ }^{3}$ Trade names are used in this publication solely for the purpose of providing specific information. Mention of a trade name does not constitute a guarantee or warranty of equipment or materials by the Agricultural Experiment Station of the University of Puerto Rico or an endorsement over other equipment or materials not mentioned. 
experimental samples was filtered and diluted to $40^{\circ} \mathrm{P}$ and set aside for one week prior to evaluation. Other similar portions were treated with powdered activated charcoal following the routine process for treating aged rum before bottling (1). Charcoal treatment was stopped when the content of tannins was similar to that of the commercial rum used as reference.

All samples were tasted by a panel of rum tasters. The reference method was employed (10): the tasters first rated a commercial rum of wide acceptance as reference; then three experimental samples per sitting were compared to the reference. Rum attributes of color, bouquet, flavor, effects on the mouth and throat, and general preference were considered and evaluated. Thirty-three evaluations per sample were performed. Panel scores on the samples were submitted to statistical analysis to determine significant differences among the reference rum and the experimental samples.

\section{RESULTS AND DISCUSSIONS}

Three weeks after the start of the experiment, two barrels stored in the hot chamber--one filled up to $50 \mathrm{gal}$ of $110^{\circ} \mathrm{P}$ spirits and the other to 50 gal of $140^{\circ} \mathrm{P}$ spirits--were found leaking through the sides of their wood stoppers. Data from both of these barrels were discarded.

Table 1 presents the physical and chemical changes after 18 weeks of aging. All data are expressed at $110^{\circ} \mathrm{P}$. Since all aged rum is diluted to the same degree proof before bottling, quantitative changes must be considered significant if they are still significant after proper dilution. Table 2 is an interpretation of the data collected in terms of alcohol and water losses at the end of the aging period. Figure 1 presents chromatograms of a rum aged in the hot chamber and in the reference chamber. Figures 2 and 3 are, respectively, graphic representations of the ethyl alcohol and water losses (loss in gal/week) during aging, after corrections were made for the decrease in total volume. Figures 4, 5 and 6 show changes in chemical composition during aging, with regard to ethyl acetate, methyl acetate and acetal contents. A discussion of the results follows.

\section{Storage loss}

The largest total rum losses (table 1) occurred in the hot chamber, (barrels 141 and 143). Average weight losses of the barrels stored at $115^{\circ}$ $\mathrm{F}$ and $80^{\circ} \mathrm{F}$ were 15.0 and 4.9 pounds, respectively -3.3 and 1.1 pounds lost per barrel per month. The $140^{\circ} \mathrm{P}$ sample lost $13 \%$ more weight than the $110^{\circ} \mathrm{P}$ samples in the hot chamber. In the reference chamber, both samples lost about the same.

Rum stored in barrels filled up to the 55 gal full capacity lost less 
Table 1.-Degree Proof, Changes in Degree Proof, Weight, and Chemical Composition of Distilled Spirits Aged for 18 Weeks at $115^{\circ} \mathrm{P}$ and $80^{\circ} \mathrm{F}$

\begin{tabular}{|c|c|c|c|c|c|c|c|}
\hline Barrel No. & & 141 & 142 & 143 & 144 & 145 & 146 \\
\hline Original volume (gal) & & 55 & 55 & 55 & 55 & 50 & 50 \\
\hline Original degree proof $\left({ }^{\circ} \mathrm{P}\right)$ & & 110 & 110 & 140 & 140 & 110 & 140 \\
\hline Temperature ${ }^{\circ} \mathrm{F}$ & & 115 & 80 & 115 & 80 & 80 & 80 \\
\hline Change in weight (pounds) & & -14.0 & -4.5 & -16.0 & -4.0 & -5.0 & -6.0 \\
\hline Component & $\begin{array}{c}\text { Original } \\
\text { concentration' }\end{array}$ & \multicolumn{6}{|c|}{ Change in concentration after 18 weeks } \\
\hline Acetaldehyde & 3.6 & +0.9 & +0.5 & +0.1 & -1.3 & +0.8 & -0.4 \\
\hline Methyl acetate & 0.4 & +2.8 & +1.1 & +2.9 & +0.9 & +1.1 & +0.9 \\
\hline Ethyl acetate & 1.6 & +30.6 & +7.4 & +23.7 & +4.7 & +8.6 & +6.8 \\
\hline Acetal & 4.6 & +4.6 & +2.5 & +6.0 & +3.8 & +1.9 & +3.7 \\
\hline Propyl alcohol & 11.6 & -0.7 & +0.5 & -0.8 & -1.2 & +0.6 & -0.1 \\
\hline Isobutyl alcohol & 5.2 & -0.5 & -0.1 & -0.5 & -0.7 & -0.1 & -0.1 \\
\hline Isoamyl alcohol & 0.5 & -0.2 & -0.1 & -0.3 & -0.2 & -0.1 & +0.1 \\
\hline Tannins & 0 & +72.0 & +36.0 & +56.0 & +34.0 & +53.0 & +43.0 \\
\hline Total acidity & 0.6 & +46.4 & +31.4 & +26.4 & +17.4 & +28.4 & +16.4 \\
\hline
\end{tabular}

'Changes in chemical concentration given in mg of component per $100 \mathrm{ml}$ of the spirit at $110^{\circ} \mathrm{P}$ 
weight than samples stored leaving a dead volume of $5 \mathrm{gal}$ in the barrel. It is pertinent to recall that the two barrels that were discarded at the beginning of the experiment because of profuse leaking were filled up originally to 50 gal. In general, it proved to be more convenient to fill the barrels to full capacity both to avoid excess rum evaporation and to make maximum use of the barrels.

\section{Degree proof}

At the end of the 18-week period the degree proof of the aging rum had decreased, except for the barrel filled up to 50 gal with $110^{\circ} \mathrm{P}$ spirits, stored in the reference chamber (table 2). The largest change was observed in the hot chamber, with the $140^{\circ} \mathrm{P}$ sample. Barrel soakage and alcohol evaporation are responsible for this initial decrease in degree proof.

Alcohol and water losses versus age (fig. 2 ad 3) show that in both chambers alcohol was lost in larger quantities than water. The largest

TABLE 2.-Change in degree proof, water and ethyl alcohol content of rums aged for eighteen weeks at $115^{\circ} \mathrm{P}$ and $80^{\circ} \mathrm{F}$

\begin{tabular}{rrcccccc}
\hline${ }^{\circ} \mathrm{P}$ & ${ }^{\circ} \mathrm{F}$ & $\begin{array}{c}\text { Original } \\
\text { volume } \\
\text { (gal) }\end{array}$ & $\begin{array}{c}\text { Change } \\
\text { in }{ }^{\circ} \mathrm{P}\end{array}$ & $\begin{array}{c}\mathrm{EtOH} \\
\text { lost } \\
\text { (gal) }\end{array}$ & $\begin{array}{c}\mathrm{H}_{2} \mathrm{O} \\
\text { lost } \\
\text { (gal) }\end{array}$ & $\begin{array}{c}\mathrm{C}^{c} \\
\text { loH }\end{array}$ & $\begin{array}{c}\mathrm{F}_{2} \mathrm{O} \\
\text { loss }\end{array}$ \\
\hline 110 & 115 & 55 & -3.3 & 3.10 & 0.90 & 10.0 & 3.7 \\
110 & 80 & 55 & -2.7 & 1.55 & 0.95 & 5.0 & 3.8 \\
140 & 115 & 55 & +3.5 & 4.20 & 0.60 & 11.0 & 3.6 \\
140 & 80 & 55 & +2.2 & 1.60 & - & 4.2 & - \\
110 & 80 & 50 & +0.3 & 0.80 & 0.60 & 3.0 & 2.6 \\
140 & 80 & 50 & -0.1 & 1.15 & 0.30 & 3.3 & 2.0 \\
\hline
\end{tabular}

total loss of alcohol, approximately $11 \%$ in 18 weeks, was registered by the $115^{\circ} \mathrm{F} 140^{\circ} \mathrm{P}$ sample in the barrel filled up to $55 \mathrm{gal}$. Alcohol losses in the reference chamber differed from those in the hot chamber by $5 \%$ at $110^{\circ} \mathrm{P}$ and $7 \%$ at $140^{\circ} \mathrm{P}$.

Rum evaporation during aging is a negative aspect of the rum aging process. Its economic implications are suffered by manufacturers and tax collectors. Since the raising of the temperature of the aging chamber from $80^{\circ} \mathrm{F}$ to $115^{\circ} \mathrm{F}$ caused a significant increase in evaporation, only a significant reduction of the aging period can justify a change. Shorter aging periods depend on the changes in composition of the maturing spirit. In general, esters and acids are convenient and aldehydes, fusel oil, acetal and tannins are unpleasant. Nevertheless, the optimum range of concentration of each substance is dependent upon its nature and the presence of other components. Changes in components in the hot cham- 


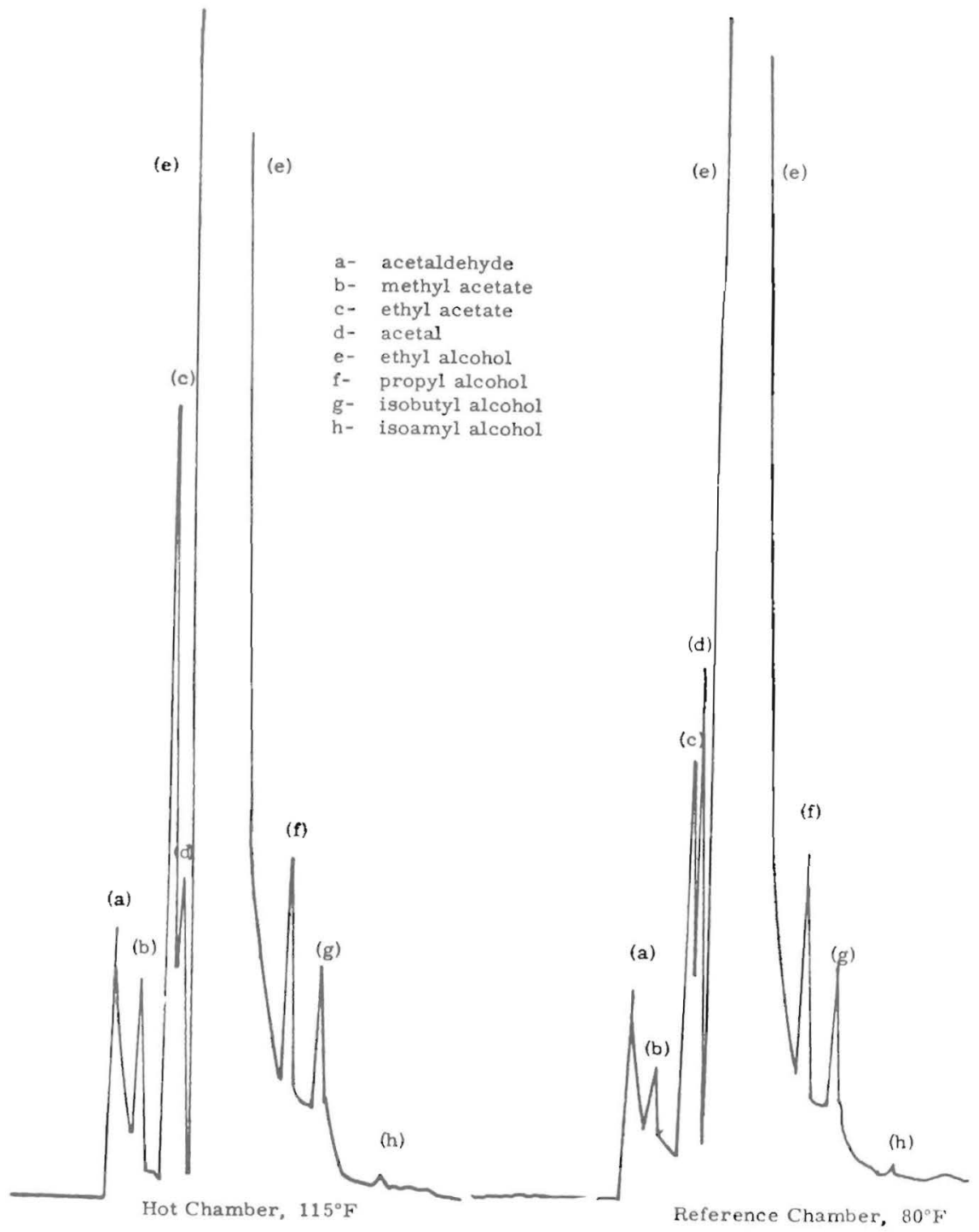

FIG. 1.-Chromatograph analysis of two rums at $115^{\circ} \mathrm{P}$ and $80^{\circ} \mathrm{F}$; representative samples.

ber were as follows:

Esters

Ethyl acetate content increased in all barrels (fig. 1). The largest increase was in the hot chamber. Eighteen-week concentrations for ethyl 


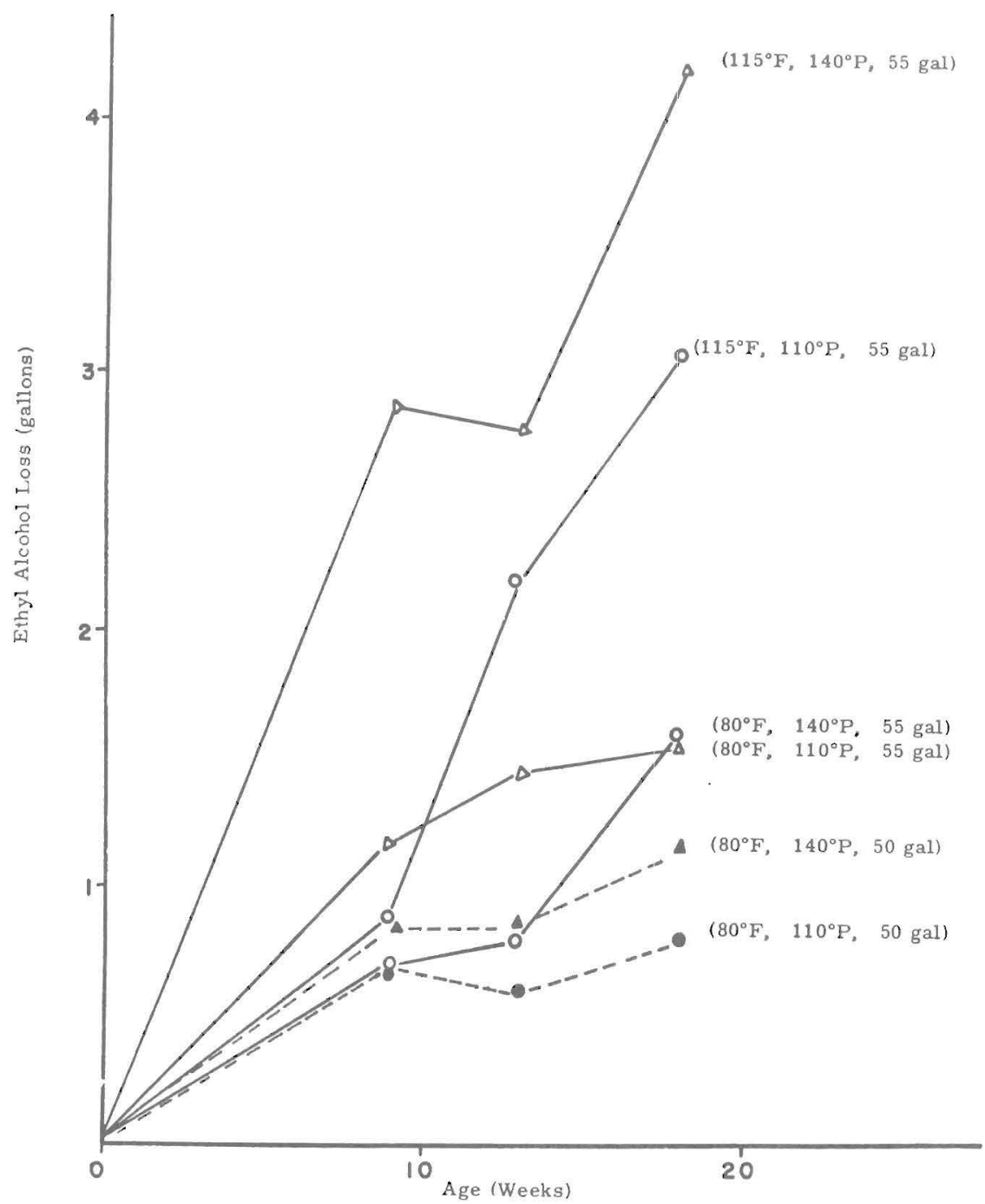

Fig. 2.-Ethyl alcohol losses during rum aging at $115^{\circ} \mathrm{P}$ and $80^{\circ} \mathrm{F}$.

acetate formation were $30.6 \mathrm{mg} / 100 \mathrm{ml}$ in the hot chamber and 7.4 $\mathrm{mg} / 100 \mathrm{ml}$ in the reference chamber, in barrels containing $55 \mathrm{gal}$ original volume. This amounts to approximately four times more ethyl acetate formed in the hot chamber. There was more formation of ethyl acetate in the barrels filled up to 50 gal than in those filled up to full capacity. More ethyl acetate was formed at $110^{\circ} \mathrm{P}$ than at $140^{\circ} \mathrm{P}$.

The hot chamber showed an average formation of methyl acetate (fig. 5) approximately three times larger than the average formation in the 


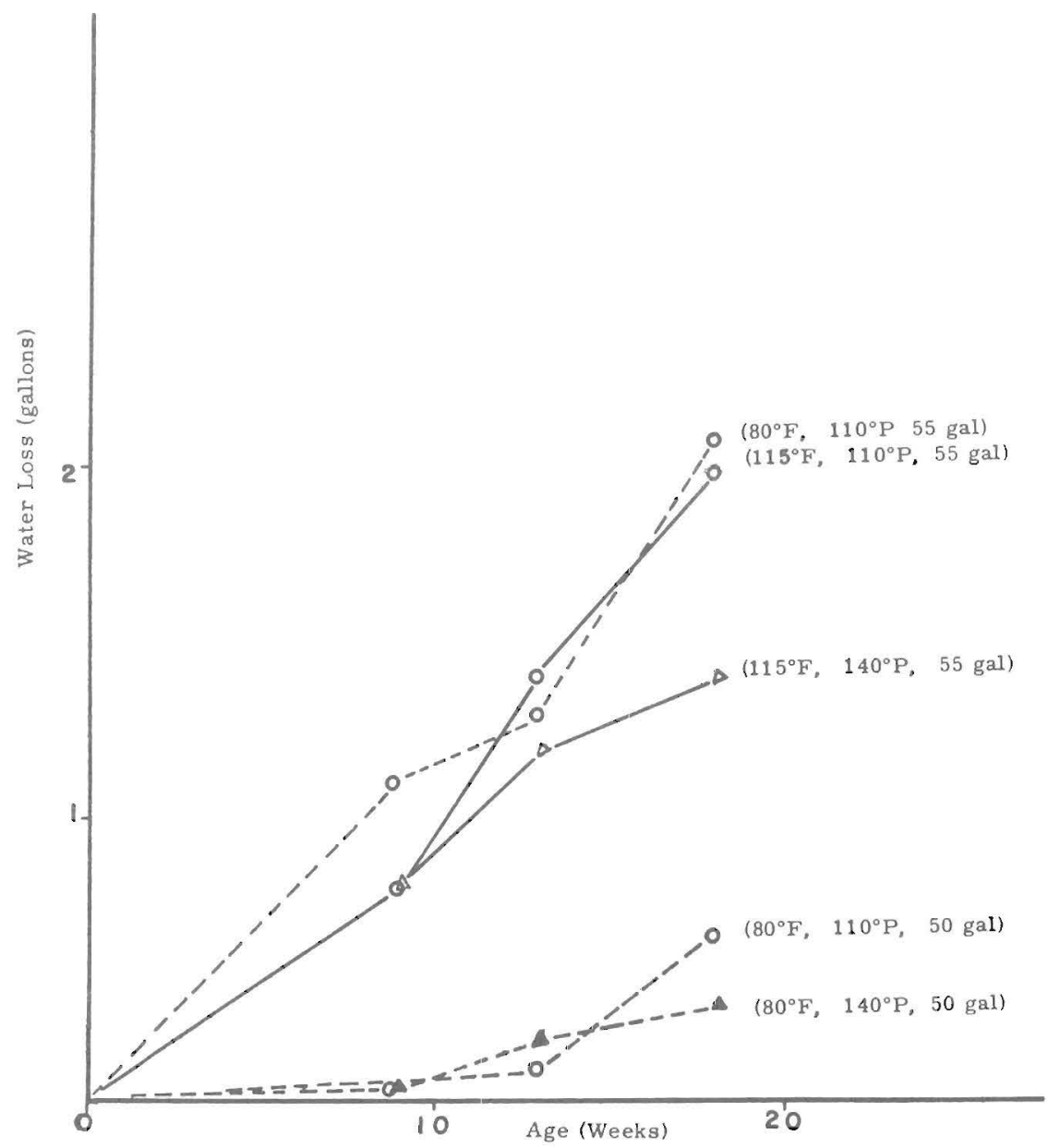

FIG. 3.-Water losses during rum aging at $115^{\circ} \mathrm{P}$ and $80^{\circ} \mathrm{F}$.

reference chamber ( 2.8 versus $1.1 \mathrm{mg} / 100 \mathrm{ml}$, at 55 gal capacity). No significant difference in methyl acetate formation was observed related to spirit degree proof or barrel original total volume.

\section{Total acidity}

More acids were produced at $115^{\circ} \mathrm{F}$ than at $80^{\circ} \mathrm{F}$ (46.4 versus 31.4 $\mathrm{mg} / 100 \mathrm{ml}$; 26.4 versus $17.4 \mathrm{mg} / 100 \mathrm{ml}$ ). In all cases more acids were produced at $110^{\circ} \mathrm{P}$ than at $140^{\circ} \mathrm{P}$. Also more acids were produced in barrels filled to full capacity than in those with 5 gallons less.

The significant increase in ester production and the smallest but also significant increase in acids, registered at $115^{\circ} \mathrm{F}$ and $110^{\circ} \mathrm{P}$, accelerated 
the maturing process, which can compensate for the increased alcohol evaporation at the highest temperature.

\section{Acetal}

Acetal increased with storage during the first 12 weeks (fig. 6). A tendency to reach a maximum level of acetal was observed at approximately that age. This tendency was similar in all samples independent of

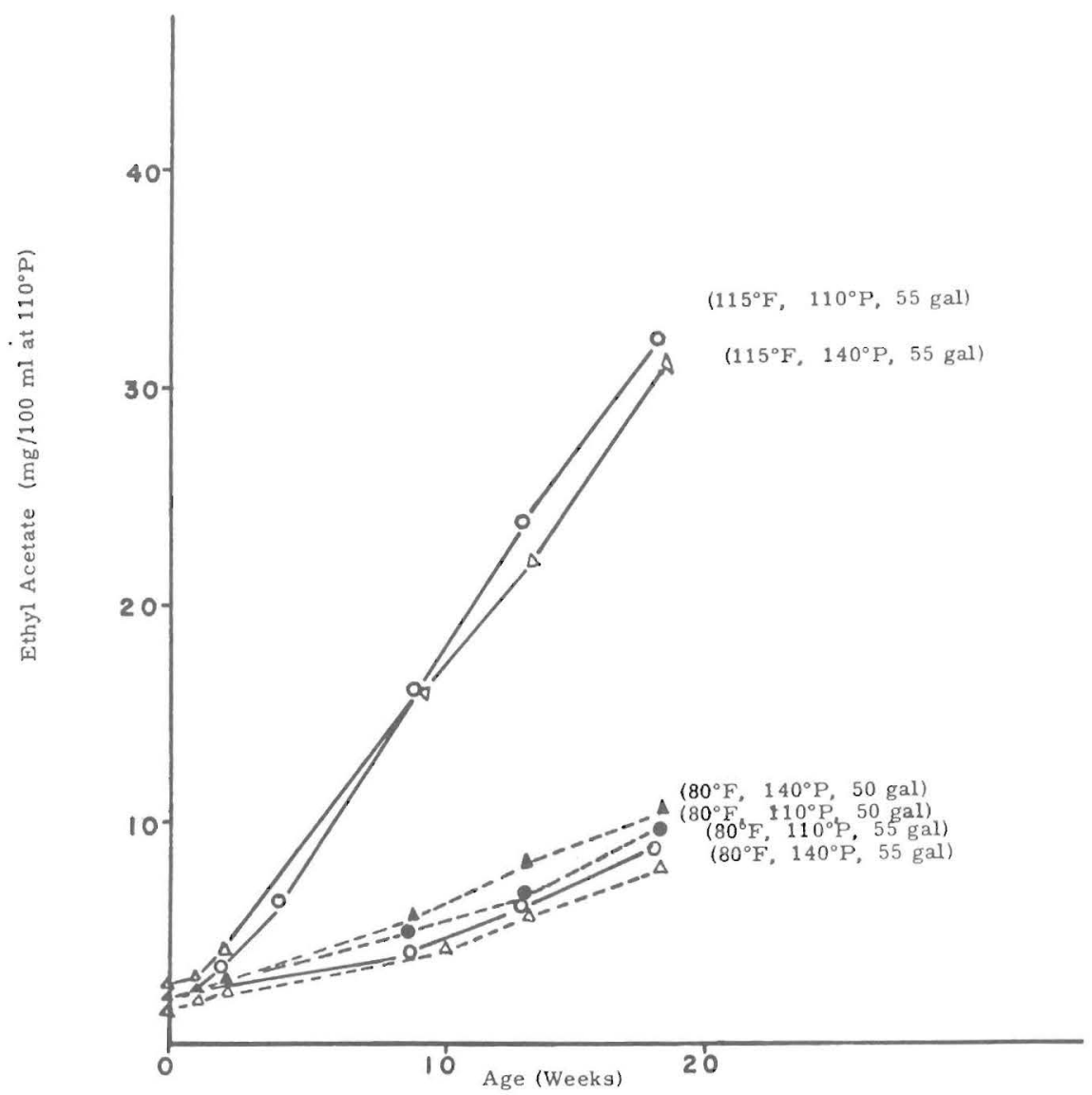

FIG. 4.-Ethyl acetate formation during aging of rum at $115^{\circ} \mathrm{P}$ and $80^{\circ} \mathrm{F}$.

any variables under study. Increases were $38 \%$ more at $115^{\circ} \mathrm{F}$ than at $80^{\circ} \mathrm{F}$, and $35 \%$ larger at $140^{\circ} \mathrm{P}$ than at $110^{\circ} \mathrm{P}$. More acetal was formed in barrels filled up to 55 gal than in those filled to 50 gal.

Acetaldehyde

In general, acetaldehyde concentration increased with age and temperature, and decreased with increase in degree proof from $110^{\circ} \mathrm{P}$ to $140^{\circ} \mathrm{P}$. 
More acetaldehyde was found in barrels originally filled up to 50 gal. Observed changes in acetaldehyde concentration were relatively small.

Fusel oil

It was observed that heavy weight alcohols were lost with age. Changes were slightly larger in the hot chamber. Losses were smaller at $110^{\circ} \mathrm{P}$ than at $140^{\circ} \mathrm{P}$, down to the observation of a slight gain in barrels stored in the reference chamber $\left(110^{\circ} \mathrm{P}, 80^{\circ} \mathrm{F}\right)$.

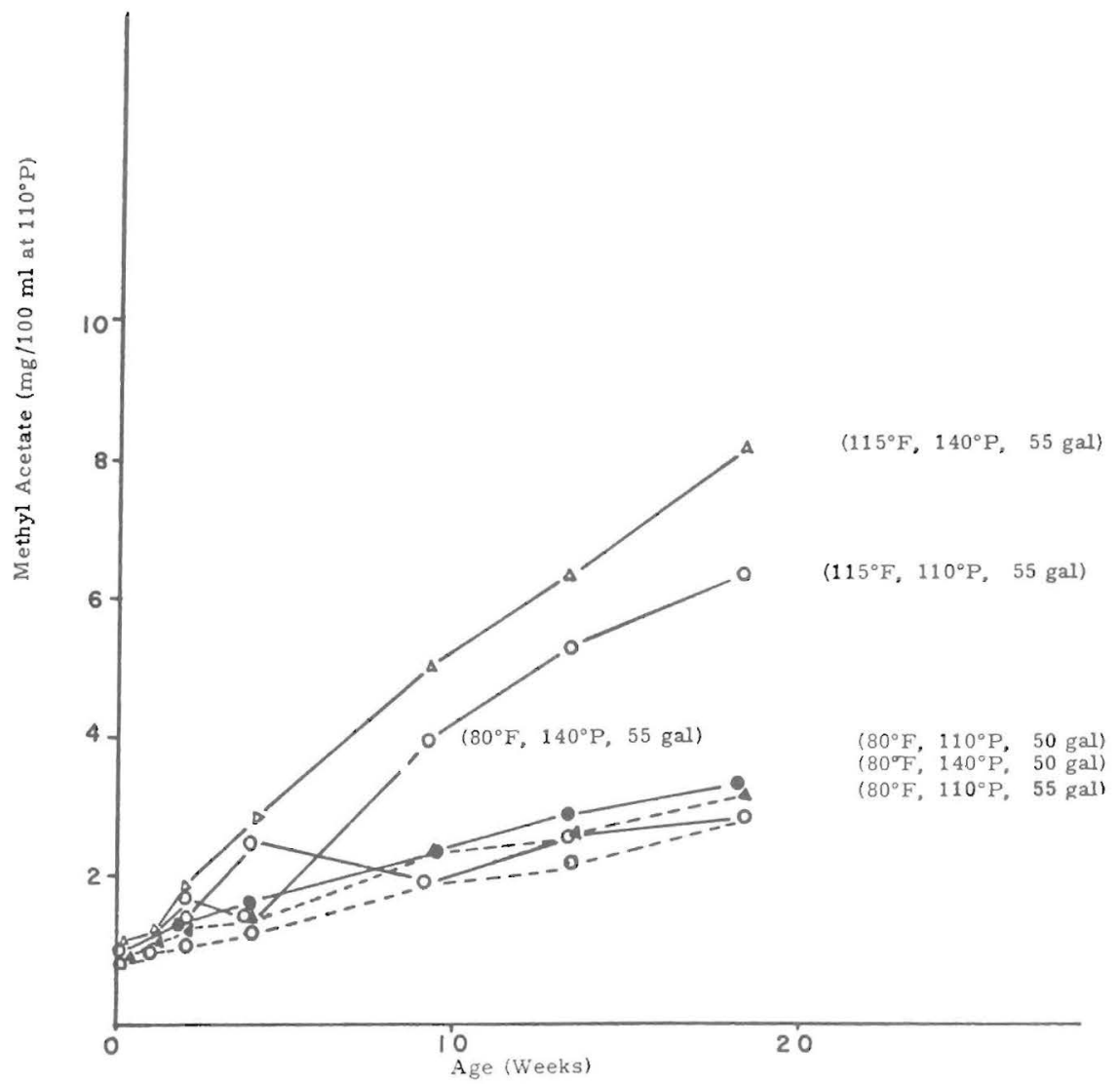

- Fig. 5.- Methyl acetate formation during aging of rum at $115^{\circ} \mathrm{P}$ and $80^{\circ} \mathrm{F}$.

\section{Tannins}

A significant acceleration in tannins extraction was achieved in the hot chamber. Fifty percent more tannins were determined in the hot chamber than in the reference chamber in $110^{\circ} \mathrm{P}$ samples. At a higher degree proof, $140^{\circ} \mathrm{P}$, tannins concentration was $39 \%$ higher in the hot chamber. In the reference chamber it was also observed that higher degree proof 


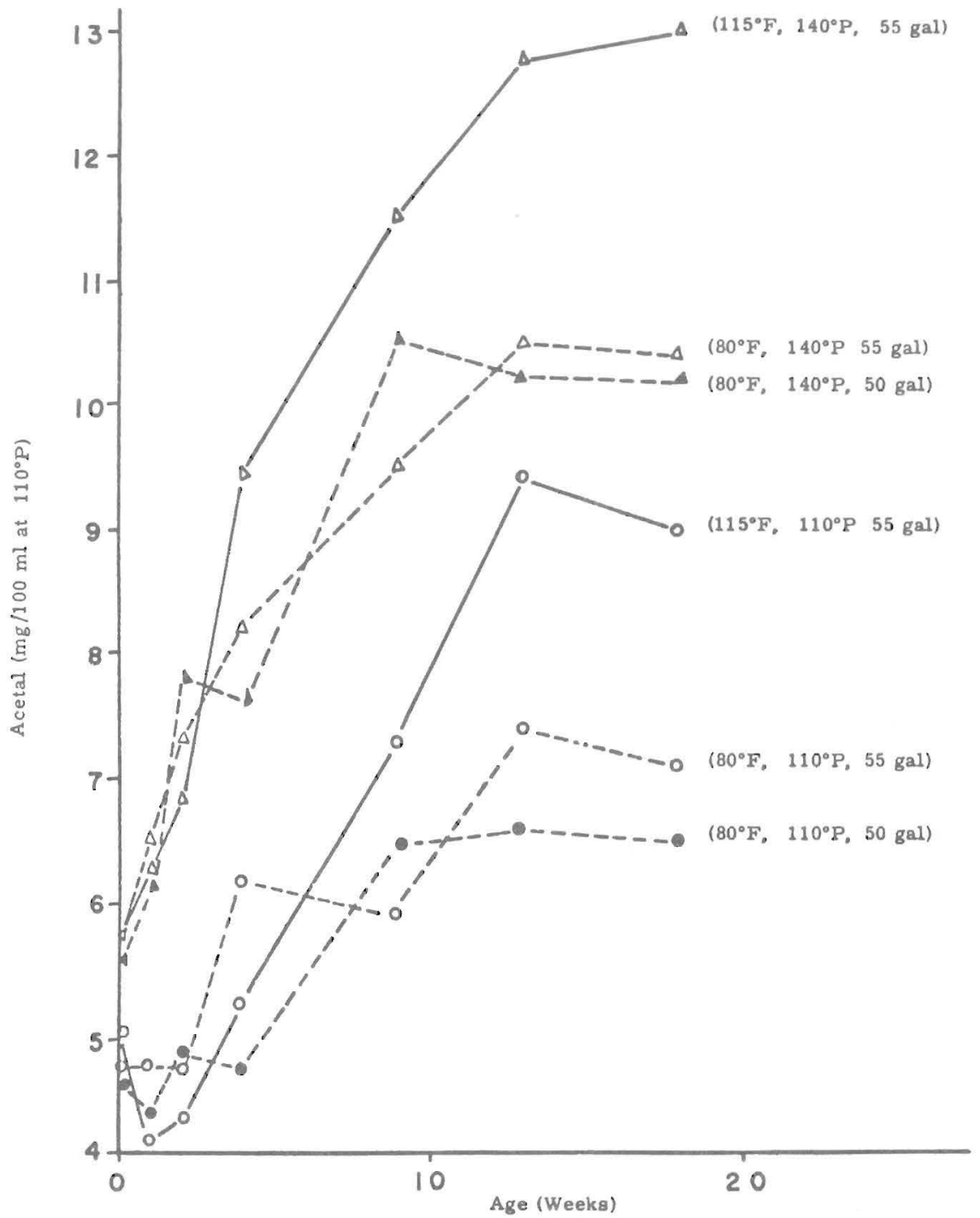

FIG. 6.-Acetal formation during aging of rum at $115^{\circ} \mathrm{P}$ and $80^{\circ} \mathrm{F}$.

samples reported less gain in tannins: $18 \%$ in barrels filled to 50 gal and $6 \%$ in barrels filled to $55 \mathrm{gal}$.

Taste evaluations (table 3)

At a 5\% level, there were no significant differences in general preference, flavor, and effect on mouth tissues among produced samples and the 
TABLE 3.-Taste evaluation of experimental aged spirits

\begin{tabular}{|c|c|c|c|c|c|c|c|c|c|c|c|}
\hline & \multirow{2}{*}{ Sample } & \multicolumn{3}{|c|}{$\begin{array}{l}\text { Effect on mouth } \\
\text { tissues }\end{array}$} & \multicolumn{2}{|c|}{ Bouquet } & \multicolumn{4}{|c|}{ Flavor } & \multirow{2}{*}{$\begin{array}{l}\text { General } \\
\text { preference }\end{array}$} \\
\hline & & & I & $\mathrm{P}$ & I & $\mathrm{P}$ & 1 & $\mathrm{P}$ & Bitterness & Acidity & \\
\hline $115^{\circ}$ & $\mathrm{F}$ & \multirow[t]{3}{*}{$\mathrm{T}$} & 2.6363 & 1.8787 & 2.5151 & 2.1212 & 2.5151 & 1.7096 & 2.3030 & 2.3076 & 1.7272 \\
\hline $110^{\circ}$ & $\mathrm{P}$ & & 2.0000 & 1.5454 & 1.8484 & 1.4687 & 2.0303 & 1.3939 & 2.0303 & 2.0357 & 1.3750 \\
\hline 55 & gal. & & & & & & & & & & \\
\hline 80 & & \multirow[t]{2}{*}{$\mathrm{T}$} & 2.7272 & 1.8181 & 2.4545 & 1.8181 & 2.6250 & 1.7096 & 2.1515 & 2.2307 & 1.5757 \\
\hline $\begin{array}{r}110 \\
55\end{array}$ & & & 2.1818 & 1.6875 & 2.0000 & 1.6666 & 2.3487 & 1.3750 & 2.3636 & 2.0740 & 1.4242 \\
\hline 115 & & \multirow[t]{3}{*}{$\mathrm{T}$} & 2.6666 & 1.8484 & 2.5454 & 1.6875 & 2.6666 & 1.7187 & 2.4242 & 2.4137 & 1.6060 \\
\hline 140 & & & 2.1515 & 1.5757 & 2.0303 & 1.4062 & 2.1212 & 1.3437 & 2.2424 & 1.9629 & 1.3636 \\
\hline 55 & & & & & & & & & & & \\
\hline 80 & & \multirow[t]{3}{*}{$\mathrm{T}$} & 2.7272 & 1.7575 & 2.6666 & 1.9062 & 2.7272 & 1.6774 & 2.1550 & 2.3333 & 1.6666 \\
\hline 140 & & & 1.9696 & 1.7272 & 1.8181 & 1.7500 & 1.9696 & 1.6060 & 2.1562 & 2.0000 & 1.6363 \\
\hline 55 & & & & & & & & & & & \\
\hline 80 & & \multirow[t]{3}{*}{$\mathrm{T}$} & 2.3333 & 1.8181 & 2.5625 & 2.0000 & 2.4848 & 1.8387 & 2.1818 & 2.2592 & 1.7812 \\
\hline 110 & & & 1.9393 & 1.5757 & 1.8787 & 1.3939 & 2.0000 & 1.4687 & 2.8707 & 1.8965 & 1.4242 \\
\hline 50 & & & & & & & & & & & \\
\hline 80 & & \multirow[t]{3}{*}{$\mathrm{T}$} & 2.6060 & 1.7575 & 2.1515 & 1.9375 & 2.5625 & 1.5806 & 2.4000 & 2.2829 & 1.5454 \\
\hline 140 & & & 2.3939 & 1.5757 & 2.1515 & 1.4242 & 2.1818 & 1.3636 & 2.2727 & 2.0000 & 1.6666 \\
\hline 50 & & & & & & & & & & & \\
\hline Refe & rence rum & & 2.000 & 2.000 & 2.000 & 2.000 & 2.000 & 2.000 & 2.0000 & 2.000 & 2.0000 \\
\hline
\end{tabular}

$\mathrm{T}=$ Activated charcoal treated for tannins and color remotion.

$\mathrm{I}=$ Intensity.

$\mathrm{P}=$ Preference. 
commercial rum used as reference sample. Rum bouquet intensity was rated as significantly richer in the $80^{\circ} \mathrm{F}-140^{\circ} \mathrm{P}-55$ gal sample as compared to the $80^{\circ} \mathrm{F}-140^{\circ} \mathrm{P}-50 \mathrm{gal}$ sample. Color intensity was found significantly higher in samples aged in the hot chamber than in samples aged in the reference chamber. Although it was not significant, there was a preference for the reference sample over experimental samples and for untreated samples over activated charcoal-treated samples. In general, charcoaltreated samples were found significantly inferior in aroma, color intensity and mouth effect, to untreated samples. Again, there was a tendency for the preference of untreated samples over treated samples, although it was not statistically significant.

\section{Safety considerations}

There exists the potential formation of an explosive mixture of alcohol, air and water in the closed hot chamber. It was also evident that the relatively high temperature of $115^{\circ} \mathrm{F}$ could be unsafe for personnel handling the samples in the hot chamber. The experiment showed that the chamber is unbearably hot; the air is low in oxygen content and heavily saturated with alcohol and water vapors. The abrupt change from the hot inside to the cool outside of the chamber may be dangerous to health.

\section{CONCLUSION}

Production of tannins, acids, esters, acetal, and acetaldehyde was accelerated in rum aging at $115^{\circ} \mathrm{F}$ as compared to environmental room temperature of $80^{\circ} \mathrm{F}$, although total rum volume, water and alcohol losses were also accelerated in the hot chamber. The lowering of barreling proof from $140^{\circ} \mathrm{P}$ to $110^{\circ} \mathrm{P}$ resulted in more acceleration and less evaporation. Rum tasters did not report significant differences in preference among either the experimental samples nor the commercial rum used as reference sample. But differences in the intensity of the rum attributes were detected among samples; hot chamber samples and noncharcoal treated samples were favored.

In general, the preliminary results obtained through this experiment called for a thorough study of the acceleration of rum aging through the raising of the temperature of the aging chamber, comparing a significant number of barrels which can provide adequate data for final conclusions.

\section{RESUMEN}

Un experimento preliminar de 18 semanas de duración demostró que el envejecimiento de ron se acelera a $115^{\circ} \mathrm{F}$ y $70 \%$ de humedad relativa. El índice para establecer el envejecimiento acelerado fue el aumento en ésteres, ácidos y taninos obtenido en la cámara caliente, comparado con la producción obtenida en la cámara de referencia, funcionando bajo condiciones ambientales de $80^{\circ} \mathrm{F}$ y $55 \%$ de humedad relativa. El contenido de acetal aumentó con la edad, con el aumento en temperatura y con el aumento en grados prueba 
de embarrilaje. La pérdida de agua, de alcohol y de volumen total del ron fue más alta en la cámara caliente. En general se encontró menor evaporación y mayor aceleración del envejecimiento a $110^{\circ} \mathrm{P}$ comparado con $140^{\circ} \mathrm{P}$ de embarrilaje. Los barriles que se llenaron hasta la capacidad total de 55 galones evidenciaron menor evaporación que los barriles que se llenaron hasta sólo 50 galones.

Un panel de catadores de ron no demostró preferencia significativa por ninguna de las muestras experimentales ni por el ron comercial usado como referencia. Sin embargo, se reportaron diferencias significativas en la intensidad de los atributos de las muestras, favoreciendo a las muestras envejecidas en la cámara caliente y a las muestras que no fueron tratadas con carbón activado.

Las condiciones de operación de la cámara caliente pueden inducir la formación de mezclas explosivas. Será necessario proveer medidas de seguridad apropiadas antes de realizar experimentos de larga duración en escala grande.

Se presentan tablas e ilustraciones gráficas de los resultados obtenidos.

\section{LITERATURE CITED}

1. Aguiar-Muxella, J. L., Rodríguez-Benitez, V., and García Morín, M., 1945, Study of the Use and Reuse of Activated Charcoal in Rum Processing, J. Agr. Univ. P. R. 52 (I): $1-18,1968$.

2. Arroyo, R., Studies on Rum, Agricultural Experiment Station, Río Piedras, Puerto Rico, Research Bulletin No. 5, 138-170.

3. Baldwin, S., R. A., Block, A. A., Andreasen, and Adams, S. L., 1959, Aromatic Congener Formation in Maturation of Alcoholic Distillates, J. Agr. Food Chem., 15, No. 3, 381-85, June 1967.

4. Brockman, M. C., Relationship Between Acids, Esters and Solids During the Aging of Whiskey, J.A.O.A.C., 33, No. 1, 127-129.

5. Crampton, C. A. and Tolman, L. M., 1908, A Study of the Changes Taking Place in Whiskey Stored in Wood, J. Am. Chem. Soc., 30, 97-136.

6. Irigoyen, J. M., 1956, Estudio Comparativo de las Curvas de Añjamiento del Ron y del Whiskey, Ciencia, 16, 225-232, México.

7. Liebmann, A. J. and Schnerl, B., 1949, Changes in Whiskey while Maturing, Ind. \& Eng. Chem., 41, No. 3, 534-43.

8. Manuel de Métodos Oficiales de la Planta Piloto de Ron, Agricultural Experiment Station, Rio Piedras.

9. Rodríguez-Benítez, V. and Camacho, B., 1960, Estudios sobre Tecnología de Ron, Agricultural Experiment Station, Rio Piedras, P. R., 31-43.

10. Torres, C., Aguiar, J. L., and Gotay, E., 1976, A Method for the Statistical Selection of a Panel of Rum Tasters, J. Agr., Univ., P. R., 60 (1), 105-112.

11. Valaer, P. and Frazier, W. H., 1956, Changes in Whiskey Stored for Four Years, Ind. \& Eng. Chem., 28, No. 1, 92-105. 